\title{
Association between family function and cigarette addiction in high school students
}

\author{
Nyoman Widhyalestari Parwatha, \\ Cokorda Bagus Jaya Lesmana, \\ Luh Nyoman Alit Aryani, \\ Wayan Westa, \\ Lely Setyawati, \\ Ni Ketut Sri Diniari
}

Department of Psychiatry, Faculty of Medicine Udayana University/Sanglah General Hospital Bali, Indonesia

\section{Cite this article:}

Parwatha NW, Lesmana CBJ, Aryani LNA, Westa W, Lely S, Diniari NKS.Association Between Family Function and Cigarette Addiction in High School Students. Journal of Clinical and Cultural Psychiatry. 2020; I (I): 9-I3.

Corresponding author:

Cokorda Bagus Jaya Lesmana

Department of Psychiatry, Faculty of Medicine Udayana University/Sanglah General Hospital J. Kesehatan No I, Bali 80I I4, Indonesia cokordabagus@unud.ac.id

\begin{abstract}
Background: Cigarette addiction not only affects physical health but also individual mental development. Family function is thought to influence the occurrence of cigarette addiction in adolescents. This study aims to determine association between family function and cigarette addiction in high school students in Denpasar.

Patients and Methods: The study participants were 138 high school students in Denpasar, aged 15-18 years. This study used analytical cross-sectional method. Measurement of family functions using the Family Assessment Device (FAD) and cigarette addiction measured by the Fagerström Test for Nicotine Dependence (FTND) questionnaire. Data was analyzed descriptively and using chi square test with significance level $\mathrm{p}<0.05$.

Results: The results showed that high school students who smoked were 29.7\%. Most high school students have good family function $(73.2 \%)$. There is an assoctiation between family function and cigarette addiction in high school students in Denpasar with OR 16.8 (95\% CI $6.7-42.1 ; \mathrm{p}<0.001)$. In this study the most important dimention from family function was the problem-solving dimension with OR 8.29 and 95\% CI 3.4-20.30 (p<0.001).

Conclusion: There is a positive association between family problem and cigarette addiction in high school students in Denpasar.
\end{abstract}

Keywords: family function, cigarette addiction, student

\section{Introduction}

High school students are in the teenage phase of development stage, which is a time of refinement from previous development stage. Adolescence is characterized by distinctive adolescent behavior, including high risk taking, exploration, sensation seeking, social interaction, activity and to learn important skills needed for maturation and independence. Smoking is a way used to improve or facilitate the interaction of adolescents with their peers. ${ }^{1}$

Cigarette consumption in Indonesia kills approximately 214,000 people every year. ${ }^{2}$ Data from Ministry of Health shows an increase in smokers prevalence each year. The prevalence of smokers over the age of 15 years, $64.9 \%$ male and $2.1 \%$ female. ${ }^{3}$ The prevalence of smokers in 1995 was $27 \%$, increased dramatically in 2013 to $36.3 \% .4$ The results of national health survey stated that smoking behavior in adolescents increased from $7.2 \% \backslash$ to $8.8 \%$ and now 9.1 percent. Research data at Jakarta Persahabatan Hospital shows that the level of addiction in high school children who smoke is quite high at $16.8 \% .^{4}$

Cigarettes contain nicotine compounds that have an addictive effect. Smoking can be a gateway for substance dependence. Substance addiction is defined as a chronic recurrence disorder 
characterized by: (1) compulsion to search for and use substances (2) loss of control in limiting intake of substances, and (3) emergence of negative emotional states (eg dysphoria, anxiety, irritability) reflecting substance withdrawal syndrome when access to the substance is prevented. ${ }^{5}$ The impact of cigarette addiction is not only on physical health but also on the mental development of an individual. ${ }^{6}$ Smoking behavior is caused not only by internal factors, but also by environmental factors including family function. Unhealthy family functions and lack of parenting skills are strongly linked to the initiation of substance use. Teenagers who have low affective relationships with parents are more likely to engage and experiment with substances including cigarettes. ${ }^{7}$

This study aims to determine the prevalence of high school students who smoke, know the function of the family and know the relationship of family function and addiction to smoking in high school students in Denpasar. The hypothesis of this study is that there is a relationship between family function and cigarette addiction in high school students in Denpasar.

\section{Material and Methods}

This study is an analytic cross sectional study to determine the relationship of family function and cigarette addiction in high school students in Denpasar. This research was conducted at high school in Denpasar starting from 1st March 2019 - 31st May 2019. Data were collected directly from research subjects (as primary data). Data collection is done using data collection sheets or questionnaires.

The inclusion criteria were male high school students in Denpasar aged 15-18 years and willing to participate in research by signing informed consent. Exclusion criteria were respondents with questionnaires that were not filled out completely or used electric cigarettes. Sampling was carried out by multistage random sampling which was divided into three stages, namely selecting high schools based on districts, selecting classes from each group of high schools and selecting students in each class that had been selected.

To measure the level of cigarette addiction used the Fagerstrom Test for Nicotine Dependence (FTND) questionnaire which is interpreted to be very low, low, medium, high and very high addiction. ${ }^{8}$ The FTND instrument has been tested for validity in Indonesia. Validity is measured by testing the questionnaire with the Pearson correlation test and showing valid for all items because the correlation test value for each item $>0.444$. Reliability was tested using the alpha model reliability analysis test and obtained a value $>0.444$ ie 0.731 , the FTND questionnaire had a level of reliability that could be trusted or could be relied on. ${ }^{9}$

The family function variable was defined as the interaction between family members measured using the McMaster Family Assessment Device (FAD) questionnaire from the McMaster Model of Family Functioning which is divided into six dimensions in the form of problem solving, communication, roles, affective responsiveness, affective involvement, behavior control ) and general functions (general functioning) that measures the health of a whole family. To find the overall family function value, all item values are divided by the total questions, if the average value of 1 and 2 is obtained, it means that the overall family function is good, if the value is above 2 , it means that the overall family function value is bad.10,11 The data obtained were analyzed with the help of statistics on a Windows 10 computer using SPSS version 24.

\section{Results}

From 140 samples selected, samples that met the inclusion criteria and filled out the questionnaire completely were 138 samples. Descriptive analysis results obtained a mean sample of $16.51 \pm 0.914$ years old (Table 1). The number of samples who smoked 41 people (29.7\%) while those who didn't smoke 97 (70.3\%) (Table 1). Based on Table 2 it appears that the majority of high school students have good family functions (73.2\%) while poor family functions are $26.8 \%$. When viewed from the dimension of family function, all dimensions function well. Distribution of samples based on smoking status obtained data from high school students who did not smoke by $70.3 \%$ while those who smoked by $29.7 \%$. Most experienced very low addiction rates $(13 \%)$. Samples that experienced low addiction and moderate addiction were $8 \%$ and $8.7 \%$, respectively. No sample experienced high and very high addiction (Table 2).

Table 1. Frequency distribution of respondent characteristics

\begin{tabular}{|c|c|c|}
\hline $\begin{array}{rr}\text { Variables } \\
\end{array}$ & Frequency & Percentage (\%) \\
\hline Age (years), mean \pm SD & $16.51 \pm 0.914$ & \\
\hline \multicolumn{3}{|l|}{ Father's occupation } \\
\hline Entrepreneur & 60 & 43.5 \\
\hline Private & 46 & 33.3 \\
\hline Government & 21 & 15.2 \\
\hline Others & 10 & 7.2 \\
\hline Unemployed & 1 & 0.7 \\
\hline \multicolumn{3}{|l|}{ Father's last education } \\
\hline Unschooled & 1 & 0.7 \\
\hline Elementary & 4 & 2.9 \\
\hline Junior High School & 6 & 4.3 \\
\hline Senior High School & 78 & 56.5 \\
\hline University & 49 & 35.5 \\
\hline \multicolumn{3}{|l|}{ Mother's occupation } \\
\hline Housewife & 49 & 35.5 \\
\hline Entrepreneur & 40 & 29.0 \\
\hline Private & 30 & 21.7 \\
\hline Government & 16 & 11.6 \\
\hline Others & 3 & 2.2 \\
\hline \multicolumn{3}{|l|}{ Mother's last education } \\
\hline Unschooled & 0 & 0 \\
\hline Elementary & 7 & 5.1 \\
\hline Junior High School & 14 & 10.1 \\
\hline Senior High School & 64 & 46.4 \\
\hline University & 53 & 38.4 \\
\hline \multicolumn{3}{|l|}{ Living arrangement } \\
\hline With parents & 124 & 89.9 \\
\hline Without parents & 14 & 10.1 \\
\hline \multicolumn{3}{|l|}{ Smoking state } \\
\hline Not smoking & 97 & 70.3 \\
\hline Smoking & 41 & 29.7 \\
\hline \multicolumn{3}{|l|}{ Smoking starting age } \\
\hline 13 years & 5 & 12.2 \\
\hline 14 years & 10 & 24.4 \\
\hline 15 years & 11 & 26.8 \\
\hline 16 years & 10 & 24.4 \\
\hline 17 years & 3 & 7.3 \\
\hline 18 years & 2 & 4.9 \\
\hline \multicolumn{3}{|l|}{ Smoking reasoning } \\
\hline Experimental & 24 & 58.5 \\
\hline Persuade by friend & 8 & 19.5 \\
\hline Seeing parents smoke & 3 & 7.3 \\
\hline Calming effect & 6 & 14.6 \\
\hline Advertigement & 0 & 0 \\
\hline \multicolumn{3}{|l|}{ Smoking father } \\
\hline Yes & 25 & 61 \\
\hline \multirow{2}{*}{\multicolumn{3}{|c|}{ Money source }} \\
\hline & & \\
\hline Parent & 35 & 85.4 \\
\hline Relative & 5 & 12.2 \\
\hline & 1 & 2.4 \\
\hline \multicolumn{3}{|l|}{ Monthly smoking expense } \\
\hline$<100,000$ & 19 & 46.3 \\
\hline $100,000-200,000$ & 13 & 31.7 \\
\hline$>200,000$ & 9 & 22 \\
\hline
\end{tabular}

In the results of the study found that $73 \%$ of poor family function experienced addiction to cigarettes, the remaining $27 \%$ did not experience addiction. Whereas in good family functioning only $13.9 \%$ experienced addiction to cigarettes and the rest were mostly non-addict- 
ed to cigarettes $(86.1 \%)$. As many as $29.7 \%$ of poor family function experienced moderate addiction, $21.6 \%$ of poor family function had low addiction and $21.6 \%$ of poor family function had very low addiction while only $1 \%$ of cigarette addiction was from families with good family function. There are differences in smoking addiction in students who have poor family function and good family function. The difference results in an odds ratio value (OR) of 16.8 with a value of $95 \%$ confidence interval (CI) 6.7 to 42.1 . This result means that poor family function influences the occurrence of cigarette addiction with OR 16.8 which is statistically significant because it does not pass 1 with a $p$ value $<0.001$ (Table 3 ).

Table 2. Sample distribution based on family function and smoking status

\begin{tabular}{|c|c|c|c|c|c|}
\hline \multirow[b]{2}{*}{ Variable } & \multicolumn{2}{|c|}{ Cigarette addiction } & \multirow[b]{2}{*}{ OR } & \multirow[b]{2}{*}{$95 \% \mathrm{CI}$} & \multirow[b]{2}{*}{$P$} \\
\hline & $\begin{array}{c}\text { Addiction } \\
\mathrm{n}(\%)\end{array}$ & $\begin{array}{c}\text { No } \\
\text { addiction } \\
\mathrm{n}(\%)\end{array}$ & & & \\
\hline \multicolumn{6}{|l|}{ Problem solving } \\
\hline $\mathrm{Bad}$ & $20(66.7)$ & $10(33.3)$ & 8.29 & $3.4-20.30$ & $<0.001 *$ \\
\hline Good & $21(19.4)$ & $87(80.6)$ & & & \\
\hline \multicolumn{6}{|l|}{ Communication } \\
\hline Bad & $14(60.9)$ & $9(39.1)$ & 5.07 & $1.98-13.0$ & $<0.001^{*}$ \\
\hline Good & $27(23.5)$ & $88(76.5)$ & & & \\
\hline \multicolumn{6}{|l|}{ Roles } \\
\hline $\mathrm{Bad}$ & $17(56.7)$ & $13(43.3)$ & 4.58 & $\begin{array}{c}1.95- \\
10.74\end{array}$ & $<0.001^{*}$ \\
\hline Good & $24(22.2)$ & $84(77.8)$ & & & \\
\hline \multicolumn{6}{|l|}{ Affective response } \\
\hline Good & $24(55.8)$ & $19(44.2)$ & 5.8 & $\begin{array}{l}2.61- \\
12.89\end{array}$ & $<0.001 *$ \\
\hline $\mathrm{Bad}$ & $17(17.9)$ & $78(82.1)$ & & & \\
\hline \multicolumn{6}{|c|}{ Affective involvement } \\
\hline Good & $29(41.4)$ & $41(58.6)$ & 3.3 & $1.51-7.23$ & $0.002 *$ \\
\hline $\mathrm{Bad}$ & $12(17.6)$ & $56(82.4)$ & & & \\
\hline \multicolumn{6}{|l|}{ Behavior control } \\
\hline Good & $34(41.5)$ & $48(58.5)$ & 4.96 & $\begin{array}{l}2.01- \\
12.27\end{array}$ & $<0.001 *$ \\
\hline $\mathrm{Bad}$ & $7(12.5)$ & $49(87.5)$ & & & \\
\hline
\end{tabular}

Table 3. Relationship between family function and cigarette addiction

\begin{tabular}{cccccc}
\hline & \multicolumn{3}{c}{ Cigarette addiction } & & \\
\cline { 2 - 3 } Variable & Addiction & $\begin{array}{c}\text { No } \\
\text { addiction }\end{array}$ & OR & $95 \% \mathrm{CI}$ & $\mathrm{p}$ \\
\hline $\begin{array}{c}\text { Family } \\
\text { function } \\
\text { Bad }\end{array}$ & $27(73.0)$ & $10(27.0)$ & 16.8 & $6.7-42.1$ & $<0.001^{*}$ \\
Good & $14(13.9)$ & $87(86.1)$ & & & \\
\hline
\end{tabular}

Table 4. Relationship of Family Function Dimensions with Cigarette Addiction

\begin{tabular}{|c|c|c|c|c|c|}
\hline \multirow[b]{2}{*}{ Variable } & \multicolumn{2}{|c|}{ Cigarette addiction } & \multirow[b]{2}{*}{ OR } & \multirow[b]{2}{*}{$95 \% \mathrm{CI}$} & \multirow[b]{2}{*}{$\mathrm{P}$} \\
\hline & $\begin{array}{c}\text { Addiction } \\
\mathrm{n}(\%)\end{array}$ & $\begin{array}{c}\text { No } \\
\text { addiction } \\
\mathrm{n}(\%)\end{array}$ & & & \\
\hline \multicolumn{6}{|l|}{ Problem solving } \\
\hline Bad & $20(66.7)$ & $10(33.3)$ & 8.29 & $3.4-20.30$ & $<0.001 *$ \\
\hline Good & $21(19.4)$ & $87(80.6)$ & & & \\
\hline \multicolumn{6}{|l|}{ Communication } \\
\hline Bad & $14(60.9)$ & $9(39.1)$ & 5.07 & $1.98-13.0$ & $<0.001 *$ \\
\hline Good & $27(23.5)$ & $88(76.5)$ & & & \\
\hline \multicolumn{6}{|l|}{ Roles } \\
\hline Bad & $17(56.7)$ & $13(43.3)$ & 4.58 & $\begin{array}{l}1.95- \\
10.74\end{array}$ & $<0.001 *$ \\
\hline Good & $24(22.2)$ & $84(77.8)$ & & & \\
\hline \multicolumn{6}{|l|}{ Affective response } \\
\hline Good & $24(55.8)$ & $19(44.2)$ & 5.8 & $\begin{array}{l}2.61- \\
12.89\end{array}$ & $<0.001 *$ \\
\hline Bad & $17(17.9)$ & $78(82.1)$ & & & \\
\hline \multicolumn{6}{|c|}{ Affective involvement } \\
\hline Good & $29(41.4)$ & $41(58.6)$ & 3.3 & $1.51-7.23$ & $0.002 *$ \\
\hline $\mathrm{Bad}$ & $12(17.6)$ & $56(82.4)$ & & & \\
\hline \multicolumn{6}{|l|}{ Behavior control } \\
\hline Good & $34(41.5)$ & $48(58.5)$ & 4.96 & $\begin{array}{l}2.01- \\
12.27\end{array}$ & $<0.001 *$ \\
\hline $\mathrm{Bad}$ & $7(12.5)$ & $49(87.5)$ & & & \\
\hline
\end{tabular}

Based on Table 4, it appears that all aspects of family function play an important role in the addiction of smoking in adolescents so that every family function must be improved. In this study, the most important dimension of family function is the problem solving dimension with an OR value of 8.29 and 95\% CI 3.4-20.30 ( $p<0.001)$, which means that the problem solving function that has a bad effect is 8.29 times the experience of cigarette addiction (Table 4).

\section{Discussion}

The habit of consuming cigarettes from a young age will be difficult to stop because smoking is addictive, even if someone gets an illness because of its bad effects. One not only inherits smoking habits from parents but also influenced the next generation. This indicates that smoking is not an individual problem but a family phenomenon, so the approach of targeting the family as a whole will tend to be more effective when formulating strategies to control cigarette use.

Initiation of smoking in early adolescents found to be higher than late adolescents. This is in accordance with the characteristics of early adolescents marked by psychological changes such as identity crisis, lability, increased verbal ability for self-expression, the importance of close friends / friends and reduced respect for parents while in late teens self-identity is stronger, able to think of ideas, able to express feelings with words, think more about the future and more stable emotions. ${ }^{12}$ Adolescents who smoke actively are positively associated with increasing anxiety early in adulthood. ${ }^{13}$ Trends in adolescent smoking behavior are a source of concern for parents, schools and health workers because cigarette use in adolescents is associated with poor health and negative behavior. Smoking in early adolescence is strongly associated with smoking habits in adulthood. ${ }^{14,15}$

Previous studies have suggested that smokers' parents are associated with a significantly higher risk of smoking initiation in adolescents. ${ }^{16}$ In this case the possibility of intergenerational smoking transmission occurs where a father is an example to his child. Children's smoking habits are inseparable from education in the family but it is also not entirely caused by parenting, but rather the influence from outside the community environment where the child is hanging out. This is also seen in the results of this study which found $58.5 \%$ of the reasons teenagers smoke because of trial and error and $19.5 \%$ because invited by friends. One that can be used to explain this phenomenon is the theory of social cognitive learning from Bandura. This theory states that individual behavior is caused by environmental, individual, and cognitive influences. ${ }^{17,18}$

The results of this study are lower than the results obtained in a study conducted by the Indonesia University economics faculty in 2013 (36.3\%) but higher than the 2018 Riskesdas data (9\%). The prevalence of smoking in this study was also lower than the prevalence of smoking in state junior high school students in Aceh Besar District (43.6\%). ${ }^{19}$ Of the students who smoked the majority of addictions were very low (13\%). This very low addiction might also be due to the fact that the school has been socialized as a non-smoking area in accordance with Denpasar City Regulation No. 7/2013 where 
non-smoking area is a room or area that is declared prohibited from smoking, composing, advertising and or promoting tobacco products. Frequent raids to attract students who carry cigarettes also include preventive activities for students to smoke. These results are lower than Pamungkas research (2014) which examined the quality of life of male smokers and non-smokers, getting low addiction results of $26.8 \%$ while moderate addiction $7.3 \%{ }^{20}$ The results obtained in this study are higher than the results of research at the Jakarta Persahabatan Hospital which shows that the level of addiction in high school children who smoke is quite high at $16.8 \%$. 4 In the sample of selected high school students none experienced high and very high addiction. This is because research is conducted at school so that if there are students who have high or very high addiction it is likely that they have a disability and are unable to attend school.

The relationship between family function and cigarette addiction is statistically significant (OR 16.8; 95\% CI 6.7-42.1; p <0.001) which means that poor family function has a risk of 16.8 times being addicted to cigarettes compared to good family function. This is in accordance with the study of Wattananonsakul et al (2014) who found Asian-American adolescents who never smoked had higher healthy family functions compared to teenagers who smoked. Other research also mentions that there is a relationship between family influence and smoking behavior in adolescents. ${ }^{21,22}$ Similar results were obtained by Riadinata (2018) who said there was a relationship between family environment and smoking behavior in adolescents in the Gonilan village, Surakarta.23 Transactional patterns of the family system is an important aspect that can shape the behavior of every family member including the decision of teenagers to smoke or not. The main function of the family is to provide all the means that can develop and maintain the social, psychological and biological aspects of all family members. ${ }^{24,25}$.

The relationship between the dimensions of family function and cigarette addiction shows a significant relationship both from the dimensions of problem solving, communication, roles, affective responses, affective involvement and behavior control (Table 4). This is consistent with the research of Hosseinbor et al (2012) which states that poor family function in the six dimensions of FAD is significantly more prevalent in addicted patients than not addiction.

The problem solving dimension in this study is the dimension of family function that has the highest risk in relation to smoking addiction. Poor problem solving in this study had a 8.29 times the risk of being a cigarette addiction compared to a good problem solving function. Well-functioning families can solve existing problems while poor family functions only pay attention to some of the problems that their families face. ${ }^{24}$ This study also resembles other studies that have found that the problem solving component has a negative and significant relationship with addiction, which means the problem solving function is poor increase the risk of smoking addiction. ${ }^{17,26}$ Better family function and parental punishment are protective factors against smoking in all three racial / ethnic groups. ${ }^{27}$
Adolescents who do not have closeness and supportive relationships with their families are more likely to be attracted to their own friends or age groups and become more vulnerable to smoking cigarettes. Teenagers who feel insecure, caused by poor family function, create a direct and significant relationship with drug abuse including smoking. Negative relationships in families and parents who do not involve themselves in the lives and problems of their children accompanied by the development of self-concept and self-control are hampered, making them more likely to smoke. ${ }^{28,29}$ Parents, especially mothers, who lack attention to the needs children cause them to fail to regulate their behavior and overcome problems in their lives so that they become vulnerable to smoking which is a risk of drug abuse, mental problems and physical health problems such as cardiovascular disease and cancer. The high prevalence of cigarette addiction in students with poor family function can be used as a guide in reducing the number of addiction and reducing the impact of cigarette addiction in the future through improving family function.

\section{Conclusion}

The prevalence of smoking in high school students in Denpasar is $29.7 \%$ with the function of the family of high school students in Denpasar mostly good that is equal to $73.2 \%$. There was a significant relationship between family function and cigarette addiction. The relationship between the dimensions of family function and cigarette addiction shows a meaningful relationship both from the dimensions of problem solving, communication, roles, affective responses, affective involvement and behavior control.

\section{Acknowledgement}

The authors report no conflict of interests.

\section{Reference}

1. Jowana S. Gangguan Mental dan Perilaku akibat Penggunaan Zat Psiikoaktif Penggunaan NAPZA/Narkoba. Edisi 2. Jakarta: Penerbit Buku Kedokteran EGC, 2005

2. Global Burden of Disease. Global Burden of Disease (GBD), Seattle,: WA: Institute for Health Metrics and Evaluation (IHME), 2015

3. Riskesdas. Riskesdas. Jakarta: Kementerian Kesehatan RI, 2013.

4. Kemenkes. Suarakan Kebenaran, Jangan Bunuh Dirimu Dengan Candu Rokok available from: http://www.depkes.go.id/article/ print/16060300002/htts-2016. Accessed Juli 2018.

5. Nutt DJ, Nestor LJ. Addiction. 1st ed. UK: Oxford University press, 2013.

6. Heatherton TF, Kozlowsky L, Frecker R, et al. The Fagerström Test for Nicotine Dependence: a revision of the Fagerström Tolerance Questionnaire. British Journal Addict. 1991;86:11191127.

7. Mulyani T. Dinamika Perilaku Merokok Pada Remaja, Surakarta: Universitas Muhammadiyah Surakarta, 2015 
8. Wattananonsakul S, Suttiwan P, Iamsupasit S. Pathways to Smoking and Drinking : The Role of Family Functioning, Supportive Parenting, Self Control, Risk and Protective Factors in Thai Adolescents. J Health Res. 2014;24(3):135-142.

9. Mufaza FY. Peran Rokok Terhadap Kualitas Hidup, Jakarta: Universitas Islam Negeri Syarif Hidayatullah, 2015.

10. Mansfield A, Keitner G, Dealy J. The Family Assessment Device:An Update. Family Procces. 2015;54:82-93.

11. Sutrisna B. Fungsi Keluarga Yang Baik Menurunkan Adiksi Internet Dan Meningkatkan Prestasi Belajar Siswa Sekolah Menengah Atas Negeri Kota Denpasar (tesis), Denpasar: Universitas Udayana, 2017.

12. Batubara JRL. Adolescence Development (Perkembangan Remaja). Sari Pediatri. 2010;12(1):21-29.

13. Moylan S, Gustavson K, Karevold E. The Impact of Smoking in Adolescence on Early Adult Anxiety Symptoms and the Relationship between Infant Vulnerability Factors for Anxiety and Early Adult Anxiety Symptoms: The TOPP Study. Adolescent Smoking and Adult Anxiety. 2013;8(5):1-11.

14. Drapela LA, Gebelt JL, McRee N. Pubertal Development, Choice of Friends, and Smoking Initiation among Adolescent Males. J Youth Adolescence. 2006;35:717-727.

15. Infodatin. Perilaku Merokok Masyarakat Indonesia. 2016. Available from : www.depkes.go.id [Accessed Juli 2018].

16. Gilman SE, Rende R, Boergers J, et al. Parental smoking and adolescent smoking initiation: an intergenerational perspective on tobacco control. Pediatrics, 2009;132(2):1-14.

17. Hosseinbor M, Bakhshani NM, Shakiba M. Family Functioning of Addicted and Non-Addicted Individuals: A Comparative Study. International Journal High Risk Behavior Addiction. 2012;1(3):109-114.

18. Kelly AB, O'Flaherty M, Connor JP. The influence of parents, siblings and peers on pre- and early-teen smoking: a multilevel model. Drug Alcohol Rev. 2011;30(4):381-387.

19. Septiana N, Syahrul S, Hermansyah H. Faktor Keluarga Yang Mempengaruhi Perilaku Merokok Pada Siswa Sekolah Menengah Pertama. Jurnal Ilmu Keperawatan. 2016;4(1):1-3
20. Pamungkas DB. Perbedaan Kualitas Hidup Laki-laki Perokok dan Non Perokok yang Diukur dengan Kuisioner SF 36v2 (Studi Pendahuluan), Jakarta: Universitas Islam Hidayatullah, 2014.

21. Kustanti AA. Hubungan Antara Pengaruh Keluarga, Pengaruh Teman dan Pengaruh Iklan terhadap Perilaku Merokok pada Remaja di SMP N 1 Slogohimo, Wonogiri, Surakarta: Fakultas Ilmu Kesehatan Universitas Muhammadiyah Surakarta, 2014.

22. Sundari AH, Uyun U. Hubungan Antara Peran Keluarga Dengan Perilaku Merokok Pada Remaja Laki-Laki Kelas Xi Di Smk Tunas Bangsa Sukoharjo, Surakarta: Universitas Muhammadiyah Surakarta, 2014

23. Riadinata E. Hubungan Lingkungan Keluarga Dan Teman Sebaya Dengan Perilaku Merokok Pada Remaja Usia 18-22 Tahun Di Desa Gonilan Kartasura, Surakarta: Program Srudi S1 Keperawatan Fakultas Ilmu Kesehatan Universitas Muhammadiyah Surakarta, 2018.

24. Epstein NB, Ryan CE, Bishop DS. The McMaster model: A view of healthy family functioning. In F. Walsh (Ed.), Normal family processes: Growing diversity and complexity. In: New York: Guilford Press. 2003:581-607.

25. Yolanda, M. Hubungan Antara Fungsi Keluarga dan Parenting Self-Efficacy Pada Ibu Bekerja (tesis). Jakarta: Universitas Indonesia, 2012.

26. Pirzadeh H, Nazari ANM, Zahrakar K, Givi RB. The role of family's function in prediction of tendency to addiction and related disorders among students (16 to 19 years). Community Health Journal. 2016; 3(1):1-10.

27. Gittens M, Xiao Y, Gordon JS, Khoury JC. The Role of Family Influences on Adolescent Smoking in Different Racial/Ethnic Groups. Nicotine \& Tobacco Research. 2012;14(3):264-273.

28. Agha S, Zia H, Irfan S. Psychological problems and family unctioning as risk factors in addiction.. J Ayub Med Coll Abbottabad. 2008;20(3):88-91.

29. Masood S, Sahar U. An exploratory research on the role of family in youth's drug addiction. Health Psychol Behav Med. 2014;2(1):820-832. 